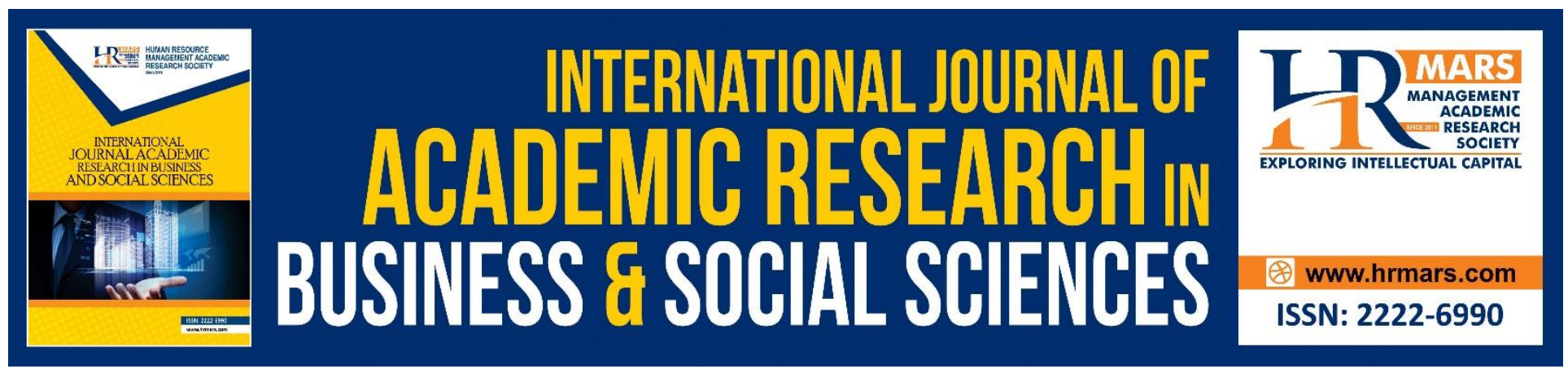

\title{
Integrating STEM Education Approach in Enhancing Higher Order Thinking Skills
}

\begin{abstract}
Norlizawaty Baharin, Nurzatulshima Kamarudin and Umi Kalthom Abdul Manaf
\end{abstract}

To Link this Article: http://dx.doi.org/10.6007/IJARBSS/v8-i7/4421

DOI: $\quad 10.6007 /$ IJARBSS/v8-i7/4421

Received: 08 June 2018, Revised: 26 June 2018, Accepted: 29 June 2018

Published Online: 16 July 2018

In-Text Citation: (Baharin, Kamarudin, \& Manaf, 2018)

To Cite this Article: Baharin, N., Kamarudin, N., \& Manaf, U. K. A. (2018). Integrating STEM Education Approach in Enhancing Higher Order Thinking Skills. International Journal of Academic Research in Business and Social Sciences, 8(7), 810-822.

Copyright: (C) 2018 The Author(s)

Published by Human Resource Management Academic Research Society (www.hrmars.com)

This article is published under the Creative Commons Attribution (CC BY 4.0) license. Anyone may reproduce, distribute, translate and create derivative works of this article (for both commercial and non-commercial purposes), subject to full attribution to the original publication and authors. The full terms of this license may be seen

at: http://creativecommons.org/licences/by/4.0/legalcode

Vol. 8, No. 7, July 2018, Pg. 810 - 822

http://hrmars.com/index.php/pages/detail/IJARBSS

JOURNAL HOMEPAGE

Full Terms \& Conditions of access and use can be found at http://hrmars.com/index.php/pages/detail/publication-ethics 


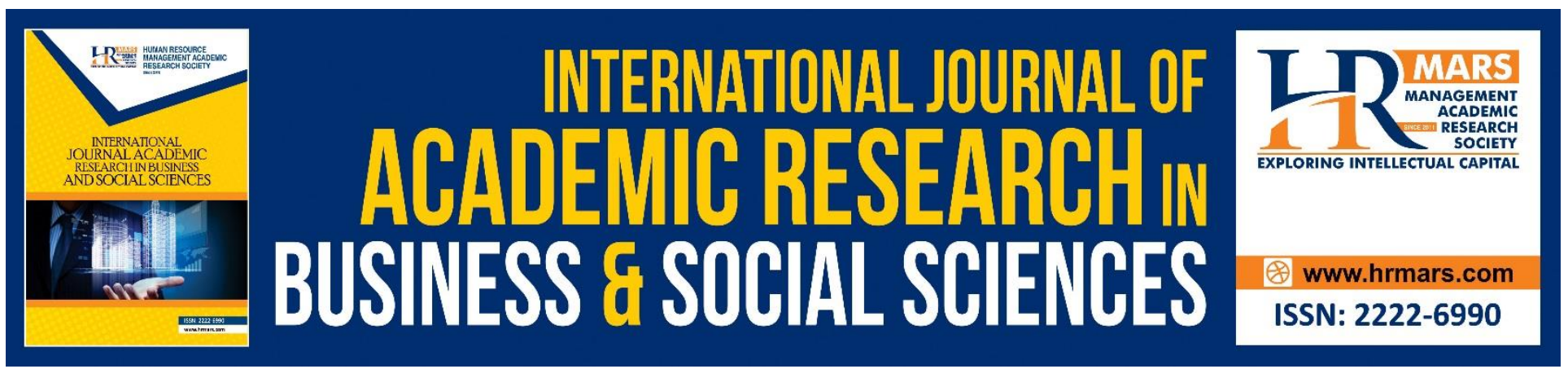

\title{
Integrating STEM Education Approach in Enhancing Higher Order Thinking Skills
}

\author{
Norlizawaty Baharin, Nurzatulshima Kamarudin and Umi Kalthom \\ Abdul Manaf
}

Faculty of Educational Studies, Universiti Putra Malaysia, 43400 UPM Serdang, Selangor, Malaysia

\begin{abstract}
The initiatives of integrating Science, Technology, Engineering and Mathematics (STEM) in the educational curriculum in schools is one of the efforts of the Ministry of Education to encourage students' interest and involvement in STEM. 21st century teaching and learning approach to STEM is one of the keys to effective learning, meaningful and deep understanding that can integrate science, technology, engineering and mathematics among students. The process of integrating STEM can be challenging because it requires a new generation that have skills in STEM fields. The approach of STEM education should include elements of problem solving, critical thinking, creative thinking and scientific thinking that can enhance higher order thinking skills (HOTS) among students. This article discusses the importance of STEM approach in the learning and teaching process that is able to enhance thinking skills among students. There are various factors and challenges to be considered in its implementation. The approaches, strategies and models that can be used to improve thinking skills among students are also discussed.
\end{abstract}

Keywords: Higher Order Thinking Skills (HOTS), Integrated STEM, STEM Pedagogies, Thinking Skill

\section{Introduction}

The education system in Malaysia today is very exam-oriented. Teaching methods in the classroom do not emphasize the pedagogy that should give the students an in-depth understanding but instead emphasizes on memorizing that does not stimulate students' thoughts. Examinations also make the minds of the students less sharpened making them less able to generate new ideas or thoughts or to think out of box. This leads the students to a focus that depends more on predicting questions and answer techniques to get excellent results in the exams. Knowledge related to intelligence is given so much encouragement to that extent that it possibly would eliminate the importance of other aspects that the students need, including emotional intelligence, spiritual intelligence, social skills and soft skills based on thinking skills, creativity and innovation. But, in line with the era of globalization and the development of the latest education system, the Ministry of Education Malaysia (MOE) has taken the initiative to transform the education of today as a whole. 
INTERNATIONAL JOURNAL OF ACADEMIC RESEARCH IN BUSINESS AND SOCIAL SCIENCES Vol. 8, No. 7, July 2018, E-ISSN: 2222-6990 @ 2018 HRMARS

Teaching in the classroom is one of the most important aspects that has been the root of the implementation of the curriculum and co-curriculum activity in the classroom. Therefore, the aspects of instruction, guidance and facilitating given in the classroom needs to be up-to-date, has high quality and is given serious emphasis. An active learning approach that encourages thinking skills should be given priority.

Malaysia's Education Development Plan (PPPM) 2013-2025 has outlined the five aspirations of the Malaysian education system to ensure Malaysian students are able to compete internationally. The five aspirations are access, quality, equity, unity and efficiency. Based on the principle of Education for All, all children in Malaysia are entitled to equal access to quality education and to ensure that all students meet the minimum standard, and passed for core subjects of Bahasa Malaysia, English, Mathematics, Science, History, and Islamic Education or Moral Education at the end of Form 5.

All students in Malaysia have the opportunity to obtain quality education that is equivalent to other countries' high performance education systems. To achieve this, the Malaysian education system needs to be improved to achieve better performance in line with the level of education of other countries according to international standards. These improvements include areas such as Mathematics, Science and English, application skills, reasoning, and problem solving. Malaysia's aspiration is to be among the top three countries in terms of performance based on international assessments such as Trends in Mathematics and Science Study (TIMSS) and Program for International Student Assessment (PISA) within 15 years.

The Malaysian education system provides the world's best education that aims to provide a bright and equitable future for all students. The Malaysian education system intends to bridge the socioeconomic gap between urban and rural areas and gender in student achievement by 2020 . This effort is expected to have an impact on the achievement gap between the state and the school type in Malaysia. Underprivileged students are given additional support to ensure that socioeconomic families do not affect their future. The Malaysian education system also provides other alternatives, including vocational education that focuses on students with special interests and talents in order to further develop their potential and thinking (Gajathiswari, Nurzatulshima \& Suhaida, 2016).

Among the main aspirations of Malaysia as a multi-racial country is to foster a solid unity. Schools are the ideal place to foster unity because the time spent by students is long in school. Interactions between students of different backgrounds can educate students to appreciate diversity and celebrate differences between races that ultimately can unify the nation. In the efforts of the Ministry to achieve the aspirations of the education system, its implementation will be carried out more effectively to maximize student success. This is a commitment by the Ministry to increase efficiency and improve the standard of education in Malaysia.

At present, there are high interests and tendencies among students and teachers towards Science, Technology, Engineering and Mathematics (STEM) education. Various approaches and teaching strategies have been proposed to provide students with the ability to master the STEM fields. The STEM education approach is expected to be able to sharpen high-level thinking skills amongst students to produce students who can become STEM experts in the future. 
INTERNATIONAL JOURNAL OF ACADEMIC RESEARCH IN BUSINESS AND SOCIAL SCIENCES Vol. 8, No. 7, July 2018, E-ISSN: 2222-6990 @ 2018 HRMARS

\section{Science, Technology, Engineering and Mathematic (STEM) Augmentation Initiative}

MOE has introduced the Science, Technology, Engineering and Mathematics (STEM) education in schools beginning 2017. STEM Education provides students with the opportunity to apply concepts and knowledge from various disciplines in an integrated way to solve problems in the real world. Pupils are actively involved in learning activities that encourage them to seek and to gain a deep understanding of the activity that is being carried out. Emphasis is given on activities involving problem solving which requires pupils to plan their own investigations. Throughout this process pupils will gain the skills to hypothesize, plan variables, design activities, make inquiries, assess and make reflections. The learning experience acquired through problem-based activities can give students an idea of what they are learning in the classroom with their everyday experiences and further enhance their problem-solving skills.

STEM Education involves learning across knowledge, skills and value of all STEM science fields. This integration makes STEM a new discipline in context that links the experiences gained in school with the reality of daily life. In the Government Transformation Program (GTP) 2013-2025, Malaysia's aspiration is to become a high-income developed country and this must be achieved through a highly educated human resource. At the same time, the Ministry of Education is given a great task compared to other ministries, the National Key Result Areas (NKRAs) that are identified as improving student performance (Abu Bakar Nordin, 2016).

The STEM Strengthening Initiative is a positive and proactive step in creating specialists in STEM to meet the needs of the Nation. This initiative also aims to increase pupils' interest through a new learning approach and curriculum enhancement, combining high level thinking skills, improving the utilization of practical teaching facilities, and making content relevant to daily life to increase interest, improve teacher skills and abilities: training for teachers at primary school and middle schools to teach revised curriculum, raise awareness among parents and pupils about STEM through national campaigns. This aspiration is expected to provide students with the opportunity to improve their skills and knowledge in the field of Science, thus enhancing their excellence internationally.

\section{STEM Education Innovation in the Curriculum}

The STEM education approach requires basic knowledge and a strong understanding of concepts to enable students to understand and apply STEM knowledge. Teachers should not only teach and hope pupils will be able to relate what they learn with their daily lives. Therefore, the STEM approach is an alternative to link STEM subjects and provide context relevant to the learning process (Kelley \& Knowles, 2016).

Malaysia's efforts to increase the number of students in the STEM field, especially in Science and Mathematics have begun since 1970 through the introduction of 60:40 Science: Literature. While this aspiration has yet to be fully achieved, the government continues to be committed on improving the quality and number of pupils in the STEM field through the 2013-2025 Malaysian Education Development Plan (PPPM). Problem-solving, project-based and scientific inquiry-based learning is an effective teaching and learning approach for STEM education (Voet \& De Wever, 2016).

Scientific activities of inquiry will provide students with thinking skills and will encourage students to ask questions, make and test hypotheses and conduct research like real scientists (Kelley \& Knowles, 
INTERNATIONAL JOURNAL OF ACADEMIC RESEARCH IN BUSINESS AND SOCIAL SCIENCES Vol. 8, No. 7, July 2018, E-ISSN: 2222-6990 @ 2018 HRMARS

2016). However, the approach to inquiry requires a deep knowledge and a neat preparation by students and teachers. Pupils can define their own learning directions and decide on what questions they want to study. To use an in-depth scientific approach requires teachers to master pedagogical content knowledge while conducting investigations.

The STEM education approach must be student-centered, cooperative learning in small groups, teachers acting as facilitators, problem solving experience in real-world contexts and acquisition of understanding is through live activities. STEM education efforts can be further strengthened through curriculum innovation, pedagogical innovation and assessment innovation (Lilia \& Mohamad Satar, 2016).

Teachers must have STEM minds and content knowledge in STEM subjects. One of the key innovations in STEM education is curriculum innovation by integrating STEM in the school curriculum. Integration of the curriculum includes four areas of 'intra-disciplinary', 'multidisciplinary', 'interdisciplinary' and 'transdisciplinary'. Intra-disciplinary is a combination of two or more topics in one subject. Multidisciplinary is a combination of two or more subjects but is still in the same set of knowledge. Combined interdisciplinary between two or more subjects but not in the same group of knowledge. Combined transdisciplinary between one of the subjects in school with other knowledge not taught at school. (Lilia \& Mohamad Satar, 2016).

Pedagogical innovation in STEM can be achieved with project-based learning approaches and problem-based learning. Pupils will be more interested in STEM subjects and able to understand well and complete the assignment. Pupils will be fun to learn, learn actively and get involved directly with inquiry and discovery activities. Implementation of the STEM approach requires the teacher to evaluate the students individually although the assignment is in the form of group work. Teachers need to ask questions at high levels according to Bloom's taxonomy at the application level, analysis, evaluation and design.

\section{Project-Based Learning Approach in Malaysia}

The three main strategies in STEM teaching and learning in Malaysia are inquiry, problem solving and project based learning. Inquiries are open ended and ongoing approach, which students using procedures used by real scientists, activity-based learning, involving repeated observations and measurements, explaining findings and students acquired information to build theories. The inquiry approach can stimulate student's curiosity that leads to instinct and desire to investigate in order to find an answer or solution to a problem. The problem-based learning method is where students solve problems using their own knowledge and capabilities collaboratively or individually. The project is defined as an ordered task, construction or investigation that is aimed at specific goals. Project-based learning involves long-term, integrating multiple disciplines, across the curriculum, student-centered and linking what's learned with real life. All of these approaches will make learning more meaningful to the students.

The five key components in project-based learning are preparation, implementation, presentation, evaluation and correction (Lou, Chou, Shih, \& Chung, 2017). Project-based learning will provide students with the experience of solving real-life problems, making students aware of real-world issues and problems, helping to promote collaborative among students, apply STEM content understanding, give students the opportunity to give ideas, improve product and apply design skills. 
INTERNATIONAL JOURNAL OF ACADEMIC RESEARCH IN BUSINESS AND SOCIAL SCIENCES Vol. 8, No. 7, July 2018, E-ISSN: 2222-6990 @ 2018 HRMARS

Project-based learning will also make the learning environment more fun and make students more motivated (Goldstein, 2016).

Why should a teacher choose a project-based learning approach? This is because the project learning approach can be carried out either individually or in groups, enabling a variety of learning methods depending on the ability of students, allowing students to make learning-related options, encouraging the use of high-level thinking skills, using hands-on experience methods, projects can be referred to by all students, involve various modes of communication. In addition, project-based learning can encourage student learning (Alsamani \& Daif-Allah, 2016; Goldstein, 2016) and encourage students to link what they have learnt before with acquired knowledge.

What are the role of a teacher to realize this project-based learning? Among these are teachers acting as facilitators, ensuring the integration of knowledge with the project, ensuring effective interaction with students throughout the process, explain the implementation procedures before the project is started and the project needs to be planned based on the skills, knowledge, experience and ability of the students.

Studies show that students studying science through project-based learning assume the environment in their class more enjoyable, satisfying, with stronger support from teachers and positive teacherstudent relationships (Hugerat, 2016). Project-based learning also enhances students' creativity, strengthens student capabilities in STEM-based learning, raises students' imaginations and curiosity (Lou, Chou, Shih, \& Chung, 2017). While research by Wekesa \& Ongunya (2016) shows that projectbased learning enables students to improve understanding and academic achievement in the topic of classification or organism. Project-based learning can also promote self-learning (Alsamani \& DaifAllah, 2016) and apply collaborative skills, reinforcing interpersonal and intercultural interactions (Goldstein, 2016).

\section{Professionalism Development Program for STEM Teachers}

Education in Malaysia now emphasizes the importance of STEM education that empowers students to learn through multi-disciplinary learning, an inquiry-based approach and problem-solving approach. Students have the opportunity to learn about science through exploration and organized research experience. To provide teachers for STEM teaching, it must begin with the enhancement of the STEM concept through relevant theories, the latest pedagogical approach and regular training.

Teachers need to be provided with training from time to time to increase their skills and knowledge, especially in the areas of knowledge and pedagogical skills so they can use the STEM approach effectively. Research also shows that teachers have less skill in implementing the STEM education approach because they do not want to change the existing teaching approach (Siew, Amir, \& Chong, 2015). This shows the need to increase STEM-based training programs for teachers.

Each relevant party needs to actively play their roles including administrators in each level such as district level, state, ministry, university and community. Professional development programs conducted at the university can support the understanding of secondary school educators and increase the ability to use STEM-based problem in classroom (Asghar, Ellington, Rice, Johnson, \& Prime, 2012). Community of practice can provide space for communities to contribute to the development of STEM in schools. Communities like scientists, engineers and experts can contribute knowledge, expertise to link STEM knowledge with real-life contexts (Kelley \& Knowles, 2016). 
INTERNATIONAL JOURNAL OF ACADEMIC RESEARCH IN BUSINESS AND SOCIAL SCIENCES Vol. 8, No. 7, July 2018, E-ISSN: 2222-6990 @ 2018 HRMARS

Studies show that STEM professional development workshops can provide support for teachers to use more innovative, creative and effective project-based STEM approaches to teaching science (Siew, Amir \& Chong, 2015). Teachers need to master the STEM teaching methodology, especially in the context of STEM subjects and appropriate pedagogy to ensure effective teaching. Teachers need to be given STEM skills through project-based learning, problem-based learning and cooperative learning. Studies show that teachers face difficulties in linking STEM disciplines during the learning process. As a result, students' interest in STEM subjects especially Mathematics and Science decreased when they failed to relate what they learned in class with various disciplines and with real life (Sun, Merrill, \& Peterson, 2001).

Studies show that professional development programs have a positive impact on the views of teachers towards STEM education. Participating teachers are able to express their views on improving the STEM education program at school. Teachers should be given training from time to time to raise awareness in the STEM field. This intention can be realized through a professional learning community (PLC) program conducted in schools to improve the efficiency of teachers to design, implement and evaluate appropriate teaching processes for the STEM approach (Altan \& Ercan, 2016).

Another government initiative in professional development of STEM teachers is to appoint a School Improvement Specialist Counselor (SISC +) to guide teachers in effective teaching and learning in the classroom. The Ministry of Education also conducts STEM video programs that involve a collection of teaching videos that can be used as guides and ideas to other teachers (Lilia \& Mohamad Satar, 2016).

\section{Higher Order Thinking Skills (HOTS) in the Curriculum}

The National Education Philosophy supports the desire to produce balanced and brilliant human beings in physical, emotional, spiritual and intellectual aspects. Education in Malaysia is expected to produce students with thinking skills, able to lead, be able to master various languages, be ethical and praiseworthy and practice strong national culture and identity.

Many educators argue that our educational system is too explicitly oriented and will make pupils more likely to use the method of memorizing and predicting questions for the purpose of achieving excellent results. Examinations also make the student's mind less interested in issuing new ideas or to think outside of the ordinary thought box (DeWitt \& Norlidah, 2016). In this regard, an effort to inculcate Higher Order Thinking Skills (HOTS) among Malaysian school students is required.

An early attempt to inculcate HOTS in Wave 1 (2013-2015) of the Malaysian Education Development Plan 2013-2025, is to improve the existing curriculum (MOE, 2013). In this regard, curriculum content has been modified to international standards with the introduction of standard curriculum for primary and secondary school (KSSR and KSSM). Information delivery systems for the curriculum implementation are also trusted by reducing the number of management layers so that the information dissemination does not occur, and the assessment framework is enhanced so there are more questions that test the HOTS.

The STEM Education Approach should include elements of problem solving, critical thinking, creative thinking and scientific thinking that can enhance HOTS among students. In addition, inquiry skills and 
INTERNATIONAL JOURNAL OF ACADEMIC RESEARCH IN BUSINESS AND SOCIAL SCIENCES Vol. 8, No. 7, July 2018, E-ISSN: 2222-6990 @ 2018 HRMARS

the ability to continue acquiring lifelong knowledge needs to be built up in each student so students can relate various knowledge and create new knowledge (Lee, Nurzatulshima, Othman \& Aminuddin, 2016; 2017). HOTS and the ability to innovate are indispensable in the fast-growing world of technology. Therefore, to focus on HOTS, the curriculum's revision is a very pivotal move.

Teaching that adopts HOTS has its own challenges. The effectiveness of teaching in the classroom is an aspect that needs to be emphasized to enable understanding of subject content and at the same time thinking skills should be taught to pupils (Nurzatulshima, Haula \& Lee, 2016). Mastery of thinking skills is one of the important aspects of student aspirations in the Malaysian Education Development Plan 2013-2025 (MOE, 2013). Teachers who implement HOTS are an important milestone for this endeavor.

Higher Order Thinking Skills (HOTS) is the ability to apply knowledge, skills and values in making reasoning and reflection to solve problems, make decisions, innovate and create something (MOE, 2013). HOTS involves applying skills, analyzing, evaluating and creating. Teachers play a role in practicing strong implementation of HOTS to improve student thinking skills. Nurzatulshima, Lee, Othman and Aminuddin (2017) revealed that using inquiry-based laboratory intervention had significantly higher in their HOTS than those students without using the intervention. Hence, the intervention gives some optimistic outcomes and directions to any educators who wish to enhance students' HOTS by using the inquiry-based teaching with the alike setting of curriculum.

In addition, the HOTS in the curriculum aims to produce students who are able to compete primarily in the evaluation of Trends in International Mathematics and Science Study (TIMSS) and the Program for International Student Assessment (PISA) internationally. However, the international examination results are very worrying because Malaysia's level is lower than our other neighboring countries (MOE, 2013). This drop has occurred even though the achievements in the English, Mathematical and Mathematical Points in the central examinations namely UPSR, Lower Secondary Assessment (PMR) and Sijil Pelajaran Malaysia (SPM) are increasing (MOE, 2013). In that regard, a system of assessments is required to test high-thinking thinking skills in learning. Such an assessment is needed to enable us to evaluate the education system in this country whether it has reached the same level as another country that earns the best position.

In order to improve the quality of education in Malaysia so that pupils produced are comparable to other countries, the ability to think and answer high-level questions is strongly emphasized. Since most of the countries are changing toward a high demand of human capital, education sector also needed to upgrade their teaching and learning system to be more effective. This can be done through more effective schooling system where teachers need to give more attention to students on how to enhancing their thinking skills to ensure that their learning lesson not only meaningful, interesting and achieve the countries' needs, but as well as enable the students to have a better and quality life for their future (Arase, Nurzatulshima, \& Aminuddin, 2016). Hence, 40 per cent of the primary school final examination (UPSR) and 50 per cent of secondary school questions will be in the form of highlevel questions from 2016 onward.

Teachers are exposed to various teaching and learning strategies that implement HOTS such as thinking tools, thinking maps, reproducing high asking questions and inquiry approaches. In order to 
INTERNATIONAL JOURNAL OF ACADEMIC RESEARCH IN BUSINESS AND SOCIAL SCIENCES Vol. 8, No. 7, July 2018, E-ISSN: 2222-6990 @ 2018 HRMARS

improve HOTS, The I-THINK Program was implemented in 10 schools in 2011 and expanded in all schools in 2014. This program aims to enhance and cultivate thinking skills among students towards creative, critical and innovative thinking students. Thinking skills are an important aspect in the development of the intellect of an individual. Thinking skills are considered to occur at the highest level in the objective taxonomy of Bloom's learning (1956), which is at the level of analysis, systematic and assessment.

\section{Challenges of STEM Teachers and STEM-Based Learning Approach}

STEM-based learning must be well designed and systematically so learning becomes active, studentcentered and provides real-life problem-solving experience. Problem-based learning models should have the following elements; Student-centered learning, problem-solving triggers for learning, selfdirected learning, co-operative learning, discussions focusing on suggestions and problem-solving measures, teachers must act as facilitators.

STEM education is relatively new in Malaysia and this is why it faces challenges especially in terms of readiness of teachers and students. Among the challenges to implement STEM-based learning is that the number of pupils with a background in STEM concepts is minimal. This is why the teacher needs to review the basic concept before giving even more difficult assignments. Many students who face the problems of not having fun in science classes causing them to face problems in mastering science understanding (Tawfik, Trueman \& Lorz, 2014). This negative attitude should be addressed to ensure STEM education approach can achieve its goals.

Another challenge is where problem-based learning is still unfamiliar to most students compared to conventional teaching and learning approaches. Students are faced with the problem of adapting to learning strategies and time management to complete a task (Tawfik Trueman \& Lorz, 2014). Students also face problems in managing their education efficiently. However, when they begin to actively engage in assignments, students will begin to cultivate interest and learn to deal with the problem.

Additionally, studies show that teachers are faced with problems in choosing tools to assess students' understanding and skills through the STEM approach. Teachers also cannot relate between assessments for the understanding of syllabus according to the teacher's stem curriculum. In conjunction to these statements, Teachers also require continuous school-based coaching and STEM in the field of teaching and assessment, to fully implement STEM education (Asghar, Ellington \& Rice, 2012).

STEM based project approaches are the latest approach in teaching and learning science. Teachers face challenges in spending time to completing their projects. Therefore, the STEM project is implemented after the completion of schooling to give teachers the opportunity to spend the syllabus and the students have enough time to complete their project. Teachers also face resource constraints, costs and infrastructure (Siew, Amir, \& Chong, 2015) in completing their projects. An immediate and proactive step should be taken by the government and the responsible party to address this problem. 
INTERNATIONAL JOURNAL OF ACADEMIC RESEARCH IN BUSINESS AND SOCIAL SCIENCES Vol. 8, No. 7, July 2018, E-ISSN: 2222-6990 @ 2018 HRMARS

The study by Lou, Shih, Diez \& Tseng (2011) found that problem-based learning can enhance student attitudes towards STEM learning and multi-career exploration in the STEM field, problem-based learning approaches can guide students to experience significant experiences in STEM knowledge and students are not only able to focus on the STEM field especially Science and Mathematics but gain a strong understanding and depth through problem-based learning in STEM education, enhancing the students' skills and abilities and providing them with learning experiences that include application and information integration. STEM subject content should be added and teachers must be provided with a learning mechanism to improve their ability.

Teaching and learning based on one-way communication such as college methods fail to produce students who master the subject's understanding and do not stimulate problem solving skills (Gallagher \& Gallagher, 2013). This method enables students to acquire knowledge in a passive way, and fail to obtain meaningful learning. STEM-based learning can motivate students to face new challenges and increase readiness and willingness to learn (Jamaludin \& Hung, 2017). The combination of Problem Based Learning (PBL) and service learning will lead to meaningful learning (Tawfik, Trueman \& Lorz, 2014).

It is important to involve students directly in learning experiences to enhance their interests, abilities and competencies, especially in the lower secondary level. Teachers will act as facilitators rather than presenter (Estes, Liu, Zha, \& Reedy, 2014). Students will work together and strive to acquire and deepen their own knowledge. Teachers need to accept these changes and with the support of the latest technology in education and curriculum that has been revamped then this dream can come true. Emphasis on pedagogy must be given more attention while learning activities must enhance knowledge, cross-curriculum skills and problem solving applications in the real world.

Problem-based learning theories focus on setting goals, self-efficacy, and outcomes or achievements. Four important stages in the problem solving process are preparation, incubation, inspiration, and verification. First, identify the problem and gather relevant information to the problem. The second is to think about the problem in the subconscious. Third is to think of a solution that is relevant to the problem. Fourth is to identify whether the proposed solution is accurate and can solve the problem (Jamaludin \& Hung, 2017).

When students are actively involved in learning, they will become more motivated, more comfortable to ask questions, to brainstorm ideas and suggest steps to solve a problem (Tawfik, Trueman \& Lorz, 2014). The new STEM learning experience encourages students to apply their knowledge to solve problems in the real world and can contribute significantly to the community.

\section{ICT Applications in Teaching and Learning at School}

The "T" in STEM refers to technology that can enhance STEM understanding. Information and communication technology (ICT) is an important aspect that has become a benchmark for the excellence of an educational organization. Students must have good skills in ICT to enable this technology to be maximized. These skills will help them to integrate their thinking skills and creativity at a high level to enable them to be a generation which capable of Creating and not just as a user. Education in schools must be able to produce students with expertise in areas such as technical and STEMs that require specialized expertise and should emphasize creativity and innovation. This 
INTERNATIONAL JOURNAL OF ACADEMIC RESEARCH IN BUSINESS AND SOCIAL SCIENCES

Vol. 8, No. 7, July 2018, E-ISSN: 2222-6990 @ 2018 HRMARS

intention is in line with the government's aspirations through the GTP (Government Transformation Program) program, ETP (Economic Transformation Program), NKRA (National Key Performance Area) and KPI (Key Performance Index) aimed at strengthening the education system in Malaysia (Hussein, $2016)$.

ICT applications will help make teaching and learning more exciting and dynamic. Students can use the ICT facilities to search for information, gain access to more creative, innovative and interactive learning materials. The ICT facility will bridge the gap between urban and rural schools where access to knowledge is only at the tip of the finger. However, it must be ensured that all teachers and students have the skills to use this ICT technology so that these facilities can contribute to meaningful and effective learning.

Students should be given the opportunity to think critically on technology and be able to see technology as an intermediary that can impact the community (Kelley \& Knowles, 2016). MOE is providing internet access and virtual learning environment through BestariNet for all 10,000 schools in Malaysia to meet the aspirations of MOE to produce all ICT-literate students and to access information. The Ministry has spent a substantial amount of funds such as Smart Schools equipped with ICT facilities. However, the study shows the use of ICT technology while the teaching and learning process is still at an unsatisfactory level.

\section{Conclusion}

21st century teaching and learning using the STEM approach is one of the key to effective, meaningful learning and in-depth understanding that can link science, technology, engineering and mathematics among students. Indeed, nowadays both students and teachers share the same responsibility to achieving better quality outcomes especially in HOTS. The role of educators is no longer narrow down to only transmitting tons of knowledge to learners but the learners needed to be educated so that they will have self-awareness in their own learning. Effective teaching and learning tend to motivate both teachers and learners to engage with their desired learning outcomes and find a best way to achieve it together. It would be great if all educators are willing to practice any new interventions to their learners in an effective learning environment (Lee, Nurzatulshima, Othman, \& Aminuddin, 2017). Thus, with the help of technological advancement, the STEM Education approach should include elements of problem solving, critical thinking, creative thinking and scientific thinking that can enhance the HOTS among students. Although many efforts have been made to improve the quality of STEM education in Malaysia, more efforts are needed to encourage pupils in Malaysia to engage in the STEM field and ensure they understand the concepts, processes and roles of science. All parties need to play a role in order for STEM education in Malaysia to be globally competitive.

\section{References}

Abu B. N. (2016). Strategi transformasi pendidikan nasional. In Hussein Ahmad \& Mohammed Sani Ibrahim (Eds). Transformasi Pendidikan Nasional Antara Aspirasi dan Anjakan. (pp. 57-70). Kuala Lumpur: Malaya University.

Alsamani, A. S., \& Daif-Allah, A. S. (2016). Introducing Project-Based Instruction in the Saudi ESP Classroom: A Study in Qassim University. English Language Teaching, 9(1), 51-64.

Baharin, N., Kamarudin, N., \& Manaf, U. K. A. (2018). Integrating STEM Education Approach in Enhancing Higher Order Thinking Skills. International Journal of Academic Research in Business 
INTERNATIONAL JOURNAL OF ACADEMIC RESEARCH IN BUSINESS AND SOCIAL SCIENCES Vol. 8, No. 7, July 2018, E-ISSN: 2222-6990 @ 2018 HRMARS

and Social Sciences, 8(7), 810-822. 